\title{
RELASI ISLAM KULTURAL DAN POLITIK ISLAM DALAM MEWUJUDKAN MASYARAKAT MADANI DI INDONESIA
}

\author{
Oleh: \\ ABDUL RAHMAN ${ }^{1}$, NURLELA ${ }^{2}$, ALFIN DWI RAHMAWAN ${ }^{3}$ \\ ${ }^{1,2}$ Fakultas Ilmu Sosial, Universitas Negeri Makasssar \\ ${ }^{3}$ Fakultas Ilmu Sosial dan Ilmu Politik, Universitas Bangka Belitung \\ 1abdul.rahman8304@unm.ac.id ${ }^{2}$ nurlela@unm.ac.id ${ }^{3}$ alfindwirahmawan98@gmail.com
}

\begin{abstract}
ABSTRAK: Artikel ini akan menguraikan posisi Islam kultural dalam kancah perpolitikan nasional. Menjadi pemahaman umum bahwa kalangan Islam kultural selalu diidentikkan dengan pesantren, hanya berkembang di kampung, berkutat dengan kitab kuning dan naskah-naskah karya ulama klasik dan cenderung abai terhadap kehidupan politik yang selalu diwarnai dengan kegaduhan. Akan tetapi, kondisi tersebut kemudian berubah, terutama pada saat Indonesia telah memasuki era reformasi, sebuah era yang memberikan kesempatan kepada semua kalangan untuk menyuarakan aspirasi politiknya. Reformasi pun telah membuka kesempatan pada ideologi-ideologi Islam transnasional yang melakukan pergerakan untuk merubah tatanan dan ideologi Pancasila sebagai ideologi yang telah disepakati oleh para pendiri bangsa ini. Gejala tersebut membangkitkan semangat kalangan Islam kultural untuk tampil berjuang di jalur politik demi mempertahankan eksistensi Negara Kesatuan Republik Indonesia (NKRI) sebagai negara yang berdaulat berdasarkan Pancasila dan Undang-Undang Dasar 1945. Perjuangan Islam kultural bukan hanya untuk menjaga kedaulatan NKRI, tetapi didorong pula untuk menampilkan citra Islam di ruang publik sebagai agama yang cinta perdamaian dan penuh toleransi serta menjunjung tinggi emansipasi kemanusiaan.
\end{abstract}

\section{Kata Kunci: Islam Kultural, Politik Islam, Masyarakat Madani}

ABSTRACT: This article will outline the position of cultural Islam in the arena of national politics. It has become a common understanding that cultural Islamists are always identified with pesantren, only developing in the village, struggling with the yellow book and manuscripts of classical scholars and tend to be ignorant of political life which is always tinged with noise. However, this condition then changed, especially when Indonesia entered the era of reform, an era that provided an opportunity for all groups to voice their political aspirations. The reformation has also opened up opportunities for transnational Islamic ideologies that are moving to change the order and ideology of the Pancasila as the ideology agreed upon by the founders of this nation. These symptoms arouse the enthusiasm of cultural Muslims to appear to struggle in the political path to maintain the existence of the Unitary State of the Republic of Indonesia (NKRI) as a sovereign state based on Pancasila and the 1945 Constitution. The struggle for cultural Islam is not only to maintain the sovereignty of the Republic of Indonesia, but is also encouraged to display the image of Islam in the public sphere as a religion that loves peace and is full of tolerance and upholds the emancipation of humanity.

KEYWORDS: Cultural Islam, Islamic politics, civil society 


\section{PENDAHULUAN}

Umat Islam meyakini dengan sepenuh hati bahwa Agama Islam yang diturunkan oleh Allah kepada Muhammad merupakan agama yang sempurna. Titik kesempurnaan itu tertuang secara tekstual dalam kitab suci al-Quran, sebagaimana yang termaktub dalam surah al-Maidah bahwa "pada hari ini telah Kusempurnakan agamamu untukmu, dan telah Kucukupkan nikmatKu kepadamu, dan telah Kuridhai Islam itu sebagai agama bagimu. Sebagai agama yang sempurna, Islam tidak hanya ditujukan untuk kemaslahatan satu kelompok, tetapi meyangkut kemaslahatan seluruh alam semesta. Islam tidak hanya mengatur satu dimensi kehidupan, tetapi mengatur seluruh aspek kehidupan sampai akhir zaman itu tiba.

Dipahami secara umum bahwa kelahiran Islam sebagai agama tidak dapat dipisahkan dari dimensi ruang dan waktu. Islam diperkenalkan oleh Muhammad sebagai nabi dan rasul yang secara wilayah berasal dari Arab. Dengan demikian, sulit dihindari akan adanya persentuhan antara Islam dengan budaya Arab. Kearaban Nabi Muhammad SAW dan al-Qur'an tidak otomatis dapat menggeneralisasi bahwa semua yang berkaitan dengan Arab itu pasti sakral, suci, dan jauh dari sisi negatif. Disinilah perlunya kearifan dalam bersikap untuk memilah antara Islam dengan Arab. Substansi ajaran Islam itulah yang patut diagungkan karena telah melampaui batas-batas peradaban, dengan menjauhi sikap saling melemahkan berdasarkan kategori suku, bangsa, dan ras (Yusqi, 2018).

Ajaran Islam menegaskan bahwa manusia diberi anugerah kehidupan oleh Allah dengan tujuan berbakti dan beribadah kepadaNya untuk kepentingan material di dunia ini sekaligus mencari keselamatan hidup di akhirat. Islam yang dimaknai sebagai upaya penyerahan diri secara total kepada Allah dalam rangka mencapai manusia yang paripurna dalam arti memiliki kepribadian yang mulia, maka seorang muslim selalu menjalin hubungan denganNya melalui ibadah ritual, sekaligus melakukan interaksi yang harmonis dengan sesama manusia untuk mencapai kesalehan sosial (Nasution, 2019). Pernyataan tersebut menujukkan bahwa Islam merupakan ajaran yang mengatur berbagai aspek kehidupan manusia. Gerak peradaban manusia akan bermakna bagi kelangsungan kemanusiaan manakala Islam dapat dijadikan sebagai landasan normatif.

Islam sebagai agama yang bercorak monoteisme dapat menjadi landasan etika dan moral dalam pertumbuhan dan perkembangan peradaban suatu bangsa jika Islam dapat dipahami sekaitan dengan peradaban manusia. Bahkan atas spirit serta kekuatan Islam akan mewujudkan suatu peradaban luhur dalam suatu bangsa. Dalam hal ini, peradaban Islam sesungguhnya adalah suatu peradaban yang memiliki kerangka pedoman berdasarkan wahyu yang diturunkan kepada Nabi Muhammad. Kedua sumber utama ajaran Islam (al-Qur'an dan alHadist) seiring dengan perkembangan zaman dan perluasan wilayah penyebaran Islam telah melahirkan sistem gagasan yang tumbuh melalui jalur-lalur pemikiran keislaman (Abdurrahman, 2012).

Islam sebagai agama dan peradaban turut mewarnai perjalanan bangsa Indonesia. Sekitar abad VII masyarakat di Nusantara telah bersentuhan dengan pedagang-pedagang Islam yang berasal dari kawasan Asia Barat dan Asia Selatan. Persentuhan tersebut telah memunculkan peradabanperadaban baru terutama di wilayah pesisir. Memasuki abad XIII Islam mulai 
melembaga dengan berdirinya KerajaanKerajaan yang bercorak Islam. Pertumbuhan kerajaan-kerajaan tersebut mendapat sokongan dari para pedagang dan muballigh, sebab mereka melihat kerajaan-kerajaan awal sebelum Islam mulai melemah karena telah kehilangan legitimasi dari masyarakat. Peran Islam sebagai kekuatan sosial dan politik turut memberikan sumbangan yang sangat besar dalam mewujudkan Indonesia sebagai negara yang berdaulat baik dalam perjuangan fisik dan diplomasi berhadapan dengan negara-negara kolonialis dari Eropa Barat dan Pendudukan militer Jepang.

Memasuki Indonesia Moderen, khususnya pada masa Orde Baru keberadaan Islam, khususnya kelompok yang meniti jalur politik berhadapan dengan sebuah konsensus, yaitu menerima Pancasila sebagai asas tunggal. konsensus tersebut menjadikan negara Indonesia bukan sebagai negara sekuler, bukan pula sebagai negara teokrasi. Oleh karena itu, religiusitas masyarakat Indonesia dan pemikiran keagamaan yang berkembang di dalamnya selalu berada pada kerangka tersebut. Demikian pula ajaran dan pemikiran agama Islam di Indonesia haruslah dipahami dengan mempertimbangkan Pancasila sebagai asas. Kondisi tersebut menyiratkan bahwa Islam pada masa Orde Baru cenderung diwarnai oleh corak-corak hinduistik, fatalistik, dan konformistik (Romas, 2000).

Pada masa Orde Baru Islam politik mengalami tekanan yang cukup berat. Dalam upaya mempersempit dan melemahkan kekuatan politik Islam, pemerintah Orde Baru mencoba menerapkan berbagai taktik dan strategi, baik dengan cara yang halus maupun cara yang kasar. Cara yang halus dilakukan dengan memberikan subsidi dan berbagai fasilitas kepada berbagai perkumpulan keagamaan (kelompok Islam kultural) yang berkiprah dalam bidang pendidikan, sosial, dakwah dan keagamaan. Sementara pada sisi lain, kelompok Islam politik, terutama partai politik Islam diberikan tindakan yang kasar, dengan cara melakukan pembersihan birokrasi dari komponen kekuatan politik Islam, termasuk pembersihan di dalam lingkungan Departemen Agama (Mubarak, 2008).

Kekuatan Islam politik semakin terdesak pasca pemilihan umum 1971. Keterdesakan tersebut ditandai dengan kebijakan pemerintah Orde Baru untuk menggabungkan partai-partai politik Islam ke dalam satu partai saja. Atas kebijakan tersebut, maka Partai Nahdlatul Ulama, Partai Muslimin Indonesia (Parmusi), Persatuan Tarbiyah Islamiyah (Perti), dan Partai Syarikat Islam Indonesia (PSII) dilebur ke dalam kelompok spiritual material yang dikenal dengan Partai Persatuan Pembangunan (PPP). Dalam perjalanannya, PPP terus mengalami konflik internal berdasarkan faksi-faksi yang menjadi cikal bakal pendirian partai tersebut (Ropik, 2013), sehingga keberadaan PPP hanya sebatas pelengkap atau asesoris politik dalam sistem ketatanegaraan Orde Baru demi menunjukkan diri sebagai pemerintahan yang demokratis.

Pasca penggabungan partai politik Islam ke dalam satu partai, keterlibatan politik umat Islam tidak pernah lagi muncul dalam bentuk yang berkualitas. Pembentukan PPP terutama dimaksudkan untuk memenuhi syaratsyarat yang diperlukan bagi adanya suatu negara yang demokratis yang dengan itu kepentingan rakyat dapat terwakili. Dalam kasus-kasus tertentu, PPP memang menjadi wakil yang terbaik bagi kepentingan umat Islam, meskipun sebagian besar tidak. Hanya dalam situasi kampanye politik saja, PPP mampu menampilkan diri sebagai perwakilan umat, tetapi pada saat selesai 
penghitungan suara, kondisi tersebut berbanding terbalik dengan perolehan suara. Pada sisi lain, keberadaan organisasi Islam nonpolitik berada pada kondisi yang menggembirakan. Dukungan pemerintah Orde Baru terhadap setiap kegiatan ormas Islam kultural sangat maksimal. Pada setiap kali muktamar Nahdlatul Ulama, kegiatan tersebut dihadiri oleh Soeharto sebagai presiden berserta pejabat-pejabat yang terkait, dan disiarkan oleh media televisi secara luas. Dukungan bukan hanya diberikan dalam bentuk finansial dan pengamanan, tetapi pasukan ABRI terlibat dalam pengadaan dapur umum untuk melayani konsumsi para peserta muktamar (Kuntowijoyo, 1991).

Memasuki awal reformasi yang ditandai dengan naiknya Baharuddin Jusuf Habibie selaku Presiden Republik Indonesia, membawa angin segar perubahan bagi aktivitas politik umat Islam. Momentum perubahan tersebut dimulai ketika pemerintah Orde Baru pada era 1990-an melakukan politik akomodasi terhadap kalangan Islam politik. Hal tersebut tidak dapat dipisahkan dengan peranan B.J Habibie sebagai orang kuat setelah Soeharto. B.J Habibie berhasil menarik kalangan Islam politik ke dalam gerbong politik Orde Baru melalui lembaga yang dibentuknya yaitu Ikatan Cendekiawan Muslim Indonesia (ICMI) dan Centre for Information and Developmnet Studies (CIDES) (Fatah, 2000). Masa reformasi dikenal sebagai era kebangkitan Islam politik, sehingga membicarakan Islam pada era reformasi merupakan hal yang kompleks karena munculnya dikotomi antara Islam politik dan Islam kultural, di mana keduanya sama-sama memiliki peran untuk mewujudkan masyarakat madani di Republik Indonesia. Dalam perjuangan tersebut ada saat-saat tertentu, Islam politik berhadap-hadapan dengan
Islam kultural, tetapi ada pula saat-saat tertentu keduanya saling bersimbiosis.

\section{METODE PENELITIAN}

Proses penulisan artikel ini menggunakan metode penelitian sejarah yang terdiri atas empat tahap. Tahapantahapan tresebut ialah (1) Heuristik, yaitu mencari jejak-jejak sejarah berupa rangkaian persitiwa yang termuat dalam catatan tertulis berupa buku, surat kabar, dan harian online. (2) Kritik, yaitu memberikan penilaian terhadap jejakjejak sejarah tersebut dengan melakukan perbandingan satu sama lain untuk menemukan fakta sejarah yang mendekati objektif. (3) Interpretasi, memberikan penafsiran terhadap jejakjejak sejarah yang telah dinilai secara objektif kemudian menghubungkannya dengan jejak-jejak sejarah yang lain sehingga tersusun cerita sejarah yang berkaitan satu sama lain (kausalitas). (4) Historiografi, kegiatan melakukan penyusunan cerita sejarah melalui laporan tertulis berupa artikel untuk ditampilkan ke hadapan publik.

\section{HASIL DAN PEMBAHASAN}

\section{Islam Kultural dan Perwujudan Masyarakat Madani}

Islam kultural didefinisikan
sebagai Islam yang melakukan
perjuangan dan gerakan di luar jalur
politik (Madjid, 1995). Islam kultural
dalam pandangan Gus Dur dimaknai
sebagai kelompok yang cenderung
menampilkan sosok Islam dalam
kesadaran sehari-hari tanpa terlalu
dikaitkan dengan kelembagaan apapun
(Muzadi, 1999). Islam kultural memiliki
keyakinan bahwa untuk memajukan
masyarakat Islam Indonesia, perjuangan
tidak selalu harus melalui jalur politik.
Memajukan masyarakat Islam Indonesia


dapat ditempuh melalui jalur pendidikan, dakwah, seni, budaya, dan kesehatan. Untuk melihat kiprah Islam kultural dalam memajukan masyarakat Islam Indonesia dalam kerangka masyarakat madani, maka Nahdlatul Ulama (NU) dan Muhammadiyah dapat dijadikan sebagai contoh.

Nahdlatul Ulama (NU) didirikan pada tanggal 31 Januari 1926 di Surabaya atas prakarsa K.H Wahab Chasbullah dan K.H Hasyim Asy'ari. NU didirikan sebagai jami'yah, yaitu sebuah organisasi keagamaan sekaligus sosial. Anggaran dasar NU menyatakan bahwa kepatuhan pada ajaran madzhab merupakan hal yang pokok. Di dalamnya dinyatakan bahwa tujuan organisasi ini ialah memegang teguh pada salah satu madzhabnya Imam empat, yaitu Imam Muhammad bin Idris asy-Syafi'i, Imam Malik bin Anas, Imam Abu Hanifah an-Nu'man, atau Imam Ahmad bin Hambal, dan mengerjakan apa saja yang menjadikan kemaslahatan agama Islam (Fealy, 2012).

Pada awal pendiriannya, NU lebih berfokus pada aspek sosial keagamaan. Akan tetapi setelah melakukan pengkajian terhadap garis perjuangan politik Islam Sunni, NU kemudian ikut ambil bagian dalam mewarnai politik pemerintahan di Republik Indonesia. NU beralasan bahwa organisasi memiliki tanggung jawab untuk menyelamatkan Islam dan para pemluknya. Untuk itu, NU harus berusaha menjaga ketentraman dan kestabilan masyarakat harus terjaga karena hal itu dipandang sebagai syarat terciptanya ketaatan dan kerukunan umat. Hanya di dalam masyarakat yang tertib, perintah Allah dapat ditegakkan, dan umat Islam dpat melaksanakan ibadahnya dengan baik. Hal itu dperlukan untuk mencapai kebahagiaan di duni dan keselamatan di akhirat. Oleh karena itu, ketentraman dan ketaatan merupakan mata rantai yang tak dapat dipisahkan.
Dalam menjalankan politik kenegaraan, NU menerapkan tiga konsep yaitu kebijaksanaan, keluwesan dan moderatisme.

Kebijaksanaan dimaksudkan sebagai pengambilan tindakan yang kondusif bagi upaya memperoleh manfaat atau menghindari kerugian. Keluwesan dimaksudkan sebagai wujud penerapan kaidah fiqih mengenai cara meminimalkan resiko. Setiap perkembangan baru dalam suatu krisis memerlukan perhitunganperhitungan baru tentang keuntungan dan kerugiannya sehingga sikap atau posisi sebelumnya dapat dipertimbangkan kembali. Moderatisme dapat diartikan sebagai suatu keinginan untuk menghindarkan tindakan yang ekstrem dan bersikap hati-hati dalam bertindak dan menyatakan pendapat. Dalam wacana politik NU, gagasan tersebut digambarkan secara jelas. Perilaku moderat, terutama kecenderungan untuk memilih cara yang umum disebut sebagai pendekatan jalan tengah (Mahatma, 2017).

Sebagai upaya untuk mewujudkan masyarakat madani di Indonesia, NU sebagai bagian dari Islam kultural menempuh beberapa cara. Pertama, mencerahkan masyarakat agar terhindar dari perilaku radikal, khususnya melalui pendidikan. Peserta didik diarahkan untuk memahami prinsipprinsip moderasi Islam, yang sesuai dengan konsep ahlus sunnah wal jama'ah. Pendidikan harus ditujukan pada pendekatan humanis pada kerangka andragogi pendidikan. Melalui pendekatan yang humanis, proses pendidikan dimaksudkan untuk menciptakan emansipasi kemanusiaan (Rozi, 2019).

Kedua, mengkondisikan masyarakat agar semakin memahami arti dan makna ukhuwah wathaniyah. Carut marut kehidupan masyarakat Indonesia sebagai bangsa yang memikul tanggung 
jawab kesatuan dan persatuan, kiranya perlu dikedepankan. NU tampil untuk menyuarakan pembelaan terhadap kasuskasus yang melanda kalangan internal anak bangsa. NU mendorong masyarakat untuk menghargai pluralisme di tengah kehidupan yang terus berubah. Konsep ukhuwah wathaniyah dal pluralisme perlu dibumikan. Masyarakat harus diberi pemahaman tentang kehidupan yang plural, bukan hanya dalam dimensi teoritis, tetapi menghadirkan sejarah kehidupan masyarakat yang plural tetapi dapat hidup berdampingan secara damai (Syam, 2009).

Ketiga, memberdayakan ekonomi umat Islam agar terbebas dari perangkap kemiskinan. Saat ini umat Islam, termasuk kalangan nahdliyin secara umum berada di wilayah pedesaan. Untuk membebaskan masyarakat dari belenggu kemiskinan, maka lembagalembaga pendidikan berupa pesantren yang dibina oleh NU harus menjadi garda terdepan untuk memberikan pendidikan kepada masyarakat baik yang berorientasi pengetahuan maupun keterampilan sebagai bekal untuk memanfaatkan dan mengelola sumber daya alam agar dapat memenuhi kebutuhan dasar masyarakat. NU melakukan gerakan ekonomi sebagai aksi melawan praktik ekonomi kapitalis serta memberikan pencerahan kepada umat untuk membebaskan diri dari sikap hidup tajrid (Irawan, 2016).

Representasi pergerakan Islam Kultural juga terwujud dalam organisasi Muhammadiyah. Muhammadiyah didirikan oleh K.H.Ahmad Dahlan di Yogyakarta pada tanggal 18 November 1912 (Siddik, 2017). Melalui Muhammadiyah, K.H Ahmad Dahlan menyebarkan modernisme Islam dengan memegang prinsip-prinsip dasar yaitu: membuka pintu ijtihad dan menolak taqlid, kembali ke al-Qur'an dan Hadist, serta menggelorakan pemurnian Islam, menolak/memberantas tahayul, bid'ah, dan khurafat. Tujuan utama Muhammadiyah ialah meluruskan segala penyelewengan yang terjadi dalam kegaiatan dakwah Islam. Penyelewangan yang terjadi dalam ajaran Islam seringkali menodai kemurnian jaran Islam karena telah terjadi pencampurbauran dengan tradisi lokal yang sesungguhnya bertentangan dengan aqidah Islam. Akan tetapi, proses pelurusan atau pemurnian jaran Islam yang dilakukan oleh Muhammdiyah tidak menempuh jalur kekerasan, tetapi dengan mengedepankan dakwah yang berupaya untuk memberikan penyadaran kepada masyarakat. Muhammadiyah dalam melakukan perjuangannya menjadi trend setter penting Islam moderat di Indonesia dalam membangun kerahmatan (rahmatan lil alamin).

Sebagai gerakan sosial keagamaan, selama ini Muhammadiyah telah menyelenggarakan pelbagai kegiatan yang bermanfaat untuk pembinaan individual maupun sosial masyarakak Islam di Indonesia. Pada level individual, cita-cita pembentukan pribadi Muslim dengan kualifikasikualifikasi etika moral Islam, terasa sangat karakteristik. Gerakan untuk membentuk keluarga sakinah, untuk membentuk jamaah, untuk membentuk qaryah thayyibah, dan pada akhirnya membentuk ummah, juga mendominasi cita-cita gerakan sosial Muhammadiyah. Pelbagai bentuk amal usaha Muhammadiyah jelas sekali membuktikan akan hal tersebut (Kuntowijoyo, 1991).

Aksi Muhammadiyah berorientasi pada semangat untuk menciptakan keteraturan sosial kemasyarakatan dan menghadirkan pendidikan yang berbasis masyarakat untuk menghasilkan sumber daya manusia yang maju dan terdidik. Muhammadiyah berusaha menampilkan Islam sebagai ajaran agama yang bukan 
hanya bersifat statis dan berorientasi pada kepentingan pribadi, tetapi dinamis dan berposisi sebagai sistem kehidupan yang universal dalam mengatur berbagai aspek kehidupan. Dalam pembentukannya, Muhammadiyah berorientasi pada aspek sosial kemasyarakatan sebagai refleksi dari perintah Allah dalam al-Qur'an, misalnya dalam Surah al-Imran ayat 104 yang tafsirannya ialah dan hendaklah ada di antara kamu sekelompok umat yang mengajak pada kebaikan, menyuruh kepada yang ma'ruf dan mencegah dari yang munkar, merekalah orang-orang yang beruntung. Ayat tersebut di kalangan elite Muhammadiyah, dimaknai sebagai perintah Allah kepada umat Islam untuk bergerak dalam menyebarkan risalah keislaman secara terorganisasi sekaligus sebagai penegasan dalam hidup berorganisasi.

Sebagai implementasi dari Surah al-Imran ayat 104, maka dalam butir ke 6 Muqaddimah Anggaran Dasar Muhammadiyah dipermaklumkan, melancarkan amal usaha dan perjuangan dengan ketertiban organisasi, yang mengandung makna pentingnya lembaga sebagai sarana gerakan yang nyata. Sebagai dampak positif dari kehadiran Muhammadiyah sebagai organisasi yang mengutamakan kesejahteraan umat, kini telah banyak dijumpai lembaga yang didirikan oleh Muhammadiyah berupa lembaga sosial, lembaga pendidikan, dan lembaga kesehatan. Berdasarkan data yang dirilis oleh wikipedia, lembaga pendidikan terdiri atas TK/TPQ sejumlah 4623, SD/MI sejumlah 2604, SMP/MTs sejumlah 1772, SMA/SMK/MA sejumlah 1143 dan perguruan tinggi sejumlah 172. Adapun lembaga sosial terdiri atas rumah sakit, balai kesehatan ibu dan anak, balai kesehatan masyarakat, balai pengobatan, dan apotek. Sedangkan lembaga yang bergerak dalam bidang sosial terdiri atas Panti Asuhan Yatim, Panti Jompo, Balai Kesehatan Sosial,
Panti Wreda/ Manula, Panti Cacat Netra, Santunan (Keluarga, Wreda/ Manula, Kematian), BPKM (Balai Pendidikan dan Keterampilan Muhammadiyah), Rehabilitasi Cacat, Sekolah Luar Biasa, dan Pondok Pesantren (https://id.wikipedia.org/wiki/Muhammadiyah).

Selain bergerak dalam domain sosial kemasyarakatan, Muhammadiyah juga melakukan gerakan intelektual. Sebagai kelompok strategis yang menghimpun kelas menengah terpelajar, Muhammadiyah tidak pernah putus dalam memproduksi kaum intelektual Muslim, yang memiliki kombinasi academic and islamic credentials sangat menawan. Secara empiris, kombinasi dan kredensialitas ini memberi manfaat bagi Muhammadiyah karena organisasi ini memiliki basis yang kuat pada komunitas Muslim, sementara tokoh-tokoh Muhammadiyah juga punya kecakapan teknikal untuk menyuarakan agendaagenda keislaman di masyarakat luas terutama kelompok nasionalis. Lapisan kelompok intelektual Muslim Muhammadiyah ini terbentuk pada setiap generasi dengan eran yang sangat menonjol sebagaimana terlihat melalui kraya-karya akademik baik dalam bentuka artikel yang terbit pada jurnal ilmiah internasional maupun buku-buku yang dihasilkan oleh berbagai penerbit domestik dan mancanegara (Fanani et al., 2015)

\section{Politik Islam dan Supremasi Rahmatan Lil Alamin}

Pemikir Islam kenamaan, Sir Muhammad Iqbal menguraikan secara cermat mengenai Politik Islam dan Islam Politik. Politik Islam dimaksudkan sebagai upaya untuk menegakkan nilainilai Islam dalam kehidupan kemasyarakatan yang berporos pada keadilan. Artinya, Islam tampil sebagai sebuah perjuangan untuk menegakkan 
keadilan, pembelaan kepada kaum tertindas, menghargai akal keberpikiran dan mendukung perkembangan ilmu pengetahuan. Perjuangan politik Islam bisa ditempuh melalui jalur partai politik, bisa juga pada kekuatan masyarakat sipil. Berbeda dengan politik Islam, Islam politik justru tampil sebagai bentuk perjuangan sekelompok orang dengan menggunakan simbol-simbol Islam untuk memperjuangkan kepentingannya dalam meraih kekuasaan yang hanya menguntungkan kelompok internalnya (Khuza'i, 2003).

Upaya untuk memperjuangkan nilai-nilai Islam dalam jalur politik mendorong beberapa tokoh Islam mendirikan Partai Kebangkitan Bangsa (PKB) pada tanggal 23 Juli 1998. Sejak pemilihan umum dilaksanakan pada era reformasi, PKB selalu masuk dalam posisi 5 besar. Sebagai partai moderen, PKB memiliki visi yaitu: (1) Mewujudkan cita-cita kemerdekaan Republik Indonesia sebagaimana dituangkan dalam Pembukaan UndangUndang Dasar 1945; (2) Mewujudkan masyarakat yang adil dan makmur secara lahir dan batin, material dan spiritual; (3) Mewujudkan tatanan politik nasional yang demokratis, terbuka, bersih dan berakhlakul karimah.

Sedangkan misi PKB yaitu: (1) Bidang Ekonomi: menegakkan dan mengembangkan kehidupan ekonomi kerakyatan yang adil dan demokratis; (2) Bidang Hukum: berusaha menegakkan dan mengembangkan negara hukum yang beradab, mampu mengayomi seluruh rakyat, menjunjung tinggi hak-hak asasi manusia, dan berkeadilan sosial; (3) Bidang Sosial Budaya: berusaha membangun budaya yang maju dan modern dengan tetap memelihara jatidiri bangsa yang baik demi meningkatkan harkat dan martabat bangsa; (4) Bidang Pendidikan: berusaha meningkatkan kualitas sumber daya manusia yang berakhlak mulia, mandiri, terampil, profesional dan kritis terhadap lingkungan sosial di sekitarnya, mengusahakan terwujudnya sistem pendidikan nasional yang berorientasi kerakyatan, murah dan berkesinambungan; (5) Bidang Pertahanan: membangun kesadaran setiap warga negara terhadap kewajiban untuk turut serta dalam usaha pertahanan negara; mendorong terwujudnya swabela masyarakat terhadap perlakuanperlakuan yang menimbulkan rasa tidak aman, baik yang datang dari pribadipribadi maupun institusi tertentu dalam masyarakat (Tribunnewswiki/Magi, 2019) .

Berdasarkan visi dan misi tersebut, PKB secara tegas menyatakan bahwa Negara Kesatuan Republik Indonesia berdasarkan Pancasila dan UUD 1945 adalah sudah final. Preferensi ini tentu berbeda dengan partai Islam lainnya yang terus berupaya memperjuangkan formalisasi syariah dalam undang-undang negara. Dengan keputusan politik fundamental itu, PKB bisa fokus dalam upaya-upaya politik yang lebih kongkrit menyangkut penyadaran, pendidikan dan pengembangan masyarakat menuju kemakmuran dan keadilan yang lebih nyata. Sementara upaya politik untuk kembali memperjuangkan negara Islam, formalisasi syariah atau memasukkan Piagam Jakarta ke dalam pembukaan UUD 1945, bukan hanya mengancam disintegrasi bangsa, tetapi juga lebih sebagai kosmetika politik belaka. (Iskandar, 2007).

Sebagai partai yang menjunjung tinggi ajaran Islam sebagai rahmatan lil alamin, PKB merupakan sarana politik untuk memperjuangkan gagasan-gagasan Islam inklusif. Postur Islam kebangsaan yang menjadi roh perjuangan $\mathrm{PKB}$ menjadi pedoman partai dalam mengayunkan langkah, sikap, dan 
kebijakan politiknya yang mencakup pola-pola aliansi dan koalisi, respons terhadap isu-isu strategis dan produk kebijakan. PKB memahami bahwa masyarakat Islam Indonesia belum sepenuhnya memiliki kesadaran dalam mewujudkan ajaran-ajaran al-Qur'an dalam menegakkan persatuan. Jika dikaitkan dengan uraian (Putra, 2019b), Islam yang ditampilkan oleh PKB ialah Islam yang menghargai kebebasan berekspresi, menunjukkan sikap toleransi, menjunjung tinggi penghormatan atas keberagaman yang tak terbilang.

Dalam mewujudkan masyarakat madani, PKB senantiasa memandang dan menyebarkan ke khalayak umum bahwa realitas masyarakat Indonesia yang beraneka ragam dalam berbagai dimensi dapat dijadikan sebagai wasilah menuju persatuan masyarakat Islam dan persatuan sesama anak bangsa melalui manajemen ikatan hati yang kuat sehingga mampu melahirkan suatu kekuatan yang dahsyat untuk membendung benih-benih radikalisme dan terorisme yang mengancam kehidupan beragama, berbangsa dan bernegara. Sikap toleransi merupakan jembatan yang berfungsi sebagai penengah dari keanekaragaman masyarakat Indonesia. Tanpa toleransi, keragaman yang dimiliki akan menjadi hambatan menuju masyarakat yang dicita-citakan, bahkan justru akan berujung pada konflik yang akan meghancurkan peradaban Islam di Indonesia.

Keanekaragaman budaya yang ada di Indonesia dalam pandangan PKB merupakan bagian dari keniscayaan sunnatullah yang tidak dapat dinafikkan. Islam menghargai dan mengakui keanekaragaman yang ditunjukkan dengan wajah suku, agama, ras, adat, dan tradisi yang disertai dengan tindakan yang berbeda-beda pula. Melihat perbedaan-perbedaan itu, PKB selalu menekankan untuk lebih mengedepankan maslahah melalui komunikasi antarbudaya, pengarus utamaan humanitas antar sesama dan penyebaran ajaran kasih sayang antar sesama manusia.

Sebagai upaya untuk menciptakan keamanan di dalam negeri, PKB terus mengkampanyekan akan pentingnya deradikalisasi. Salah satu upaya itu ialah melalui pengarusutamaan Islam moderat. Penciri Islam moderat yaitu menjunjung tinggi keadilan, menjaga keseimbangan, serta bersikap toleran dan respek kepada pihak lain (Prasetiawati, 2017). Islam moderat ialah penerimaan dan penghormatan terhadap perbedaan, terbuka bagi orang lain, dan kesediaan mengembangkan kerjasama dengan kelompok yang berbeda (Suprapto, 2020). Untuk mewujudkan Islam moderat, PKB bekerjasama dengan lembaga-lembaga pendidikan, khususnya pesantren untuk melaksanakan gerakan dakwah yang ramah sebagai komitmen untuk meneguhkan keadaban Islam sebagai agama rahmatan lil alamin, sekaligus menegakkan keadaban Indonesia sebagai negara multikultural yang harus menjunjung tinggi semangat persatuan, keadilan, dan kesejahteraan bersama. Dengan demikian nampak jelas bahwa PKB dalam arus perjuangannya berusaha mewujudkan humanisme transendental sebagai manusia yang sama-sama berasal dari Tuhan yang satu.

\section{Islam Kultural di Jalur Politik}

Memasuki era reformasi, keran demokrasi telah terbuka dengan baik. Hal tersebut dapat dilihat dari fokus utama demokrasi, perluasan hak rakyat atas negara, akses pemerintahan, serta kebebasan aspirasi dan menjunjung tinggi nilai kemanusiaan, sebagai warga negara yang terlibat dalam tata pemerintahan. 
Sehingga publik diberikan kesempatan yang luas untuk ikut berpartisipasi dalam tahapan pengambilan keputusan. Keterlibatan masyarakat dalam pengambilan keputusan sudah sepatutnya menjadi pertimbangan pemerintah jika hendak mengambil kebijakan .

Era reformasi telah mengantarkan bangsa ini ke tingkat pengalaman politik baru yang sangat menarik. Suatu harapan politik yang tidak saja merupakan konsekuensi dari tuntutan cita-cita reformasi. Namun, desakan tentang pentingnya perubahan atau reform itu sekarang telah menjadi kehendak dan prakarsa politik yang diperjuangkan oleh rakyat sendiri. Hal ini memiliki indikasi yang kuat bahwa rakyat tidak lagi memilih atas dasar pertimbangan partai belaka. Sesungguhnya, rakyat sebagai warga negara sudah menggunakan kemerdekaan politiknya untuk menilai, siapa pemimpin yang layak dapat dipertimbangkan karena dapat dipercaya mampu membawa perubahan masa depan. Timbulnya partisipasi politik rakyat secara bebas dan tidak terikat oleh apapun merupakan satu kemajuan dalam praktik demokrasi di Indonesia.

Meningkatnya partisipasi masyarakat untuk terlibat aktif dalam proses-proses politik telah mendorong berbagai kalangan untuk ikut berjuang di jalur politik sebagai komitmen mereka untuk mewujudkan masyarakat madani. Iklim demokrasi yang semakin sejuk pada era reformasi memberikan kesempatan kepada siapa pun, termasuk ulama dan intelektual untuk memilih dan dipilih dalam sebuah perhelatan pemilihan umum, baik sebagai calon eksekutif maupun calon legislatif. Hal tersebut dapat dilihat pada komposisi anggota legislatif yang di dalamnya terdapat elite-elite NU. Keterlibatan ulama dan intelektual dari kalangan NU jika dilihat dalam perspektif (Putra, 2019a) merupakan usaha mereka membentuk karakter melalui penguatan integritas demi tercapainya kondisi pemerintahan yang berpihak pada masyarakat.

Keterlibatan elite NU dalam jalur politik tetap mengacu pada ideologi Ahlussunnah wal Jama'ah. Ideologi tersebut merupakan filsafat politik atau kaidah fiqh yang sering dirujuk oleh para ulama dan politisi NU dalam menghadapi persoalan. Kaidah fiqh yang dimaksud ialah (1) Dar'ul mafasid muqaddamun 'ala jalbi al-mashalih (menghindari kerusakan/kemudaratan lebih diutamakan daripada meraih kebaikan/kemaslahatan. (2) Idza ta'aradha masfadatani ru'ya 'azhamuha dhararan bi-irtikaabi akhaffahima (jika dihadapkan pada dua masalah yang samasama mengandung bahaya maka pilihlah salah satu dari keduanya yang bahayanya lebih sedikit/kecil. (3) Ad'dararu la yuzalu bi ad-dirar (suatu bahay tidak boleh dihilangkan dengan sesuatu yang bisa mendatangkan bahaya yang lain (Fealy, 2012).

Ketiga prinsip politik tersebut kemudian dijabarkan lebih rinci pada hasil keputusan Muktamar NU pada tahun 1989 yaitu: (1) Berpolitik bagi Nahdlatul Ulama mengandung arti keterlibatan warga negara dalam kehidupan berbangsa dan bernegara secara menyeluruh sesuai dengan Pancasila dan UUD1945. (2) Politik bagi Nahdlatul Ulama adalah politik yang berwawasan kebangsaan dan menuju integrasi bangsa dengan langkah-langkah yang senantiasa menjunjung tinggi persatuan dan kesatuan untuk mencapai cita-cita bersama, yaitu terwujudnya mamsyarakat adil dan makmur lahir dan batin dan dilakukan sebagai amal ibadah menuju kebahagiaan di dunia dan kehidupan di akhirat. (3) Politik bagi Nahdlatul Ulama adalah pengembanagan nilai-nilai kemerdekaaan yang hakiki dan demokratis, mendidik kedewasaan 
bangsa untuk menyadari hak, kewajiban dan tanggung jawab untuk mencapai kemaslahatan bersama. (4) Berpolitik bagi Nahdlatul Ulama haruslah dilakukan dengan moral, etika dan budaya yang berketuhanan Yang Maha Esa, berperikemanusiaan yang adil dan beradab, menjunjung tinggi persatuan Indonesia, berkerakyatan yang dipimpin oleh hikmat kebijakasanaan dalam permusyawaratan/perwakilan, dan berkeadilan sosial bagi seluruh rakyat Indonesia. (5) Berpolitik bagi Nahdlatul Ulama haruslah dilakukan dengan kejujuran nurani dan moral agama, konstitusional, adil sesuai dengan peraturan dan norma-norma yang disepakati, serta dapat mengembangkan mekanisme musyawarah dalam memecahkan masalah bersama. (6) Berpolitik bagi Nahdlatul Ulama dilakukan untuk memperkokoh konsensus-konsensus nasional, dan dilaksanakan sesuai dengan akhlakul karimah sebagai pengamalan ajaran Islam Ahlussunnah wal Jamaah. (7) Berpolitik bagi Nahdlatul Ulama, dengan dalih apapun tidak boleh dilakukan dengan mengorbankan kepentingan bersama dan memecahbelah persatuan. (8) Perbedan pandangan di antara aspirasi-aspirasi politik warga Nahdlatul Ulama harus tetap berjalan dalam suasana persaudaraan, tawadlu' dan saling menghargai satu sama lain, sehingga dalam berpolitik itu tetap dijaga persatuan dan kesatuan di lingkungan Nahdlatul Ulama. (9) Berpolitik bagi Nahdlatul Ulama menuntut adanya komunikasi kemasyarakatan timbal balik dalam pembangunan nasional untuk menciptakan iklim yang memungkinkan perkembangan organisiasi kemasyarakatan yang lebih mandiri dan mampu melaksanakan fungsinya sebagai sarana masyarakat untuk berserikat, menyalurkan aspirasi serta berpartisipasi dalam pembangunan (Fathoni, 2018).
Filsafat politik tersebut kemudian diimplementasikan bagi elite NU dalam kancah perpolitikan nasional. Hal tersebut merupakan respon terhadap tantangan yang dihadapi oleh NU sebagai pelopor Islam moderat di Negara Indonesia. Tantangan tersebut ialah kemunculan penetrasi ideologi Islam transnasional yang menjelma ke dalam ormas-ormas yang mengatasnamakan Islam dalam perjuangannya, tetapi aksiaksi mereka diwarnai dengan kekerasan yang bertentangan dengan ajaran Islam. Ormas-ormas radikal tersebut berusaha untuk merubah Pancasila sebagai ideologi Negara Kesatuan Republik Indonesia, dan berusaha untuk menerapkan formalisme Islam dalam kehidupan berbangsa dan bernegara.

Salah satu partai yang lebih dominan dihuni oleh elite $\mathrm{NU}$ dalam perjuangan politiknya ialah $\mathrm{PKB}$. PKB selalu menggaungkan akan pentingnya persaudaraan kebangsaan tanpa adanya sekat-sekat antara anak bangsa. Bagi PKB negara ini harus berdiri tegak menolak segala bentuk deskriminasi dan kesenjangan sosial. Hal itu dibuktikan ketika Abdurrahman Wahid sebagai tokoh utama PKB mencabut Inpres Nomor 14 Tahun 1967 lantaran bertentangan dengan UUD 1945. Inpres tersebut selama bertahun-tahun menyandera etnis Tionghoa karena tak dapat merayakan hari-hari besar seperti Imlek dan Cap Go Meh atau beribadah secara terbuka. Setelah mencabutnya, Gus Dur menerbitkan Keppres No. 6 tahun 2000 yang menjamin warga Tionghoa dapat menjalankan kegiatan keagamaan,kepercayaan, dan adat istiadatnya secara terbuka (https://m.medcom.id/nasional/politik/3 NOBdgXK-pkb-komitmen-mewujudkan-politik-kebangsaan)

Hasil perjuangan ulama dan intelektual NU yang paling berharga, terutama di kalngan umat Islam ialah 
diterbitkannya Undang-Undang Pesantren. Disahkannya Rancangan Undang-Undang Pesantren dan Pendidikan Keagamaan sebagai RUU inisiatif DPR memberi harapan baru dalam upaya pemberdayaan pesantren yang selama ini kurang mendapatkan perhatian dari negara sebagaimana lembaga pendidikan lainnya (Niam, 2018). Disahkannya UU Pesantren menjadi hadiah terindah bagi seluruh santri di tanah air. Semua menyadari bahwa pesantren adalah pusat peradaban Islam di Indonesia yang selalu setia terhadap bangsa dan negara. Karena itu, sudah menjadi kewajiban tersendiri bagi PKB sebagai parpol yang lahir dari rahim NU untuk memperjuangkan eksistensi pesantren secara konstitusional. Perjuangan PKB itu juga atas amanah langsung dari para kiai kepada ketua umum PKB (Gus AMI) terkait dengan pentingnya pengakuan negara terhadap posisi pesantren (Wahid, 2019).

\section{PENUTUP}

Kemunculan kalangan Islam kultural dalam arena perpolitikan nasional tidak dapat dipisahkan dari kondisi Bangsa Indonesia setelah memasuki era reformasi. Reformasi telah disalahpahami oleh sebagian pihak, dengan memanfaatkan momentum reformasi itu untuk meyampaikan hasrat politiknya, walaupun bertentangan dengan prinsip-prinsip Pancasila dan UUD 1945 sebagai dasar negara. Reformasi yang telah disalahartikan itu memunculkan kekhawatiran bagi kalangan Islam kultural akan nasib bangsa Indonesia di masa yang akan datang. Terjadinya aksi-aksi kekerasan yang dilakukan oleh sekelompok ormas yang mengatasnamakan Islam dinilai akan merapuhkan semangat kebangsaan dan memunculkan penilaian yang negatif terhadap Islam sebagai agama yang rahmatan lil alamin. Perjuangan Islam kultural untuk menegakkan marwah bangsa Indonesia dan Agama Islam ditempuh melalui aksi-aksi sosial kemasyarakatan misalnya dakwah dan kegiatan pendidikan baik di sekolahsekolah umum maupun di lingkungan pondok pesantren. Selain itu ditempuh pula melalui jalur politik dengan cara meraih jabatan publik baik di lembaga eksekutif dan legislatif dengan harapan dapat mewujudkan praktek-praktek politik yang mengedepankan kepentingan kebangsaan, kenegaraan, dan keagamaan.

\section{DAFTAR PUSTAKA}

Abdurrahman, D. (2012). Sejarah Peradaban Islam: Dari Masa Klasik Hingga Modern. Yogyakarta: LESFI.

Fanani, A. F., Burhani, A. N., Alhumami, A., Khoirudin, A., Wahid, D., Thohari, H. Y., ZTF, P. B. (2015). Islam Berkemajuan Untuk Peradaban Dunia. Bandung: Mizan Pustaka.

Fatah, E. S. (2000). Agenda-Agenda Besar Demokratisasi Pasca Orde Baru. Bandung: Mizan.

Fathoni. (2018). Pedoman Berpolitik Warga NU. Retrieved from https://www.nu.or.id/post/read/ 94013/pedoman-berpolitikwarga-nu

Fealy, G. (2012). Ijtihad Politik Ulama; Sejarah NU 1952-1967 (Vol. 1). Yogyakarta: Lkis.

Irawan, R. A. (2016). Etos Pemberdayaan Ekonomi Masyarakat NU. Episteme: Jurnal Pengembangan Ilmu Keislaman, 11(1), 149-162.

Iskandar, A. M. (2007). Gus Dur, Islam, dan kebangkitan Indonesia. Yogyakarta: KLIK. R.

Khuza'i, R. (2003). Pemikiran Politik Mohammad Iqbal. Mimbar: 
Jurnal Sosial dan Pembangunan, 19 (2), 179-194.

Kuntowijoyo. (1991). Paradigma Islam : Interpretasi Untuk Aksi. Bandung: Mizan.

Madjid, N. (1995). Islam: Agama Kemanusiaan: Membangun Tradisi Dan Visi Baru Islam Indonesia. Jakarta: Yayasan Wakaf Paramadina.

Mahatma, M. (2017). Paradigma Politik Nahdlatul Ulama (NU) dalam Bernegara. Mawa'izh: Jurnal Dakwah Dan Pengembangan Sosial Kemanusiaan, 8(1), 3154.

Mubarak, M. Z. (2008). Genealogi Islam Radikal Di Indonesia: Gerakan, Pemikiran, Dan Prospek Demokrasi. Jakarta: LP3ES.

Muzadi, A. H. (1999). Membangun NU Pasca Gus Dur: Dari Sunan Bonang Sampai Paman Sam. Jakarta: Gramedia Widiasarana Indonesia.

Nasution, H. (2019). Islam Ditinjau Dari Berbagai Aspeknya. Jakarta: Universitas Indonesia.

Niam, A. M. (2018). UU Pesantren, Menuju Pesantren yang Lebih Berdaya. Retrieved from https://www.nu.or.id/post/read/ 96127/uu-pesantren-menujupesantren-yang-lebih-berdaya

Prasetiawati, E. (2017). Menanamkan Islam Moderat untuk Menanggulangi Radikalisme di Indonesia. Fikri: Jurnal Kajian Agama, Sosial Dan Budaya, 2(2), 523-570.

Putra, D. K. S. (2019a). Komunikasi CSR Politik: Membangun Reputasi, Etika, Dan Estetika PR Politik. Jakarta: Prenada Media.

Putra, D. K. S. (2019b). Political Sosial Responsibilty: Dinamika Komunikasi Politik Dialogis. Jakarta: Prenadamedia Group.
Romas, C. S. (2000). Wacana Teologi Islam Kontemporer. Yogyakarta: Tiara Wacana.

Ropik, A. (2013). Islam Dan Sosial Politik Dekade 1990-An (Sebuah Wacana Politik Islam Pasca Orde Baru). Wardah, 14 (2), 177-186.

Rozi, S. (2019). Pendidikan Moderasi Islam KH. Asep Saifuddin Chalim; Mencegah Radikalisme Agama dan Mewujudkan Masyarakat Madani Indonesia. TARBIYA ISLAMIA: Jurnal Pendidikan Dan Keislaman, 8(1), 26-43.

Siddik, D. (2017). Dinamika Organisasi Muhammadiyah di Sumatera Utara. Dalam Journal of Contemporary Islam and Muslim Societies, 1 (1).

Suprapto. (2020). Istiqamah di Jalur Tengah: Penguatan Demokrasi Beragama di Pascasarjana PTKIN. In A. Wijaya (Ed.), Berislam Di Jalur Tengah. Yogyakarta: Ircisod.

Syam, N. (2009). Tantangan Multikulturalisme Indonesia: Dari radikalisme Menuju $\mathrm{Ke}$ bangsaan. Yogyakarta: Kanisius.

Tribunnewswiki/Magi. (2019). Partai Kebangkitan Bangsa. Retrieved April 5, 2020, from https://www.tribunnewswiki.co $\mathrm{m} / 2019 / 08 / 21 /$ partaikebangkitan-bangsa

Wahid, M. H. (2019). UU Pesantren Jadi Kado Terindah. Jawapos. Retrieved from https://www.jawapos.com/opini/22/10/2019/uu -pesantren-jadi-kado-terindah/ Yusqi, M. I. (2018). Islam, NU, dan Nusantara. In A. M. Niam (Ed.), Mozaik Pemikiran Islam Nusantara. Jakarta: Numedia Digital Indonesia. 